\title{
PENGARUH PENYULUHAN TENTANG PERAWATAN BERAT BADAN LAHIR RENDAH (BBLR) TERHADAP PENGETAHUAN IBU MERAWAT BAYI BERAT BADAN LAHIR RENDAH
}

\author{
Mardiana \\ Akademi Keperawatan Batari Toja Watampone \\ Alamat Korespondensi: (dianaizzan@gmail.com/085333555760)
}

\begin{abstract}
ABSTRAK
Bayi dengan BBLR memiliki risiko lebih tinggi mengalami kematian, keterlambatan petumbuhan dan perkembangan selama masa kanak-kanak dibandingkan dengan bayi yang tidak BBLR. Bayi berat badan lahir rendah (BBLR) adalah bayi baru lahir dengan berat badan kurang dari 2500 gram pada waktu lahir. Tujuan penelitian ini adalah Untuk mengetahui pengaruh penyuluhan tentang perawatan BBLR terhadap kemampuan ibu dalam merawat bayi BBLR. Penelitian merupakan penelitian quasy eksperiment dengan pendekatan pre test dan post test. Pengambilan sampel pada penelitian ini menggunakan tehnik total sampling, jumlah sampel dalam penelitian ini adalah sebanyak 15 responden kelompok eksperimen dan 15 responden pada kelompok kontrol. Instrumen yang digunakan dalam penelitian ini adalah kuesioner. Data dianalisis menggunakan program SPSS dengan uji statistik uji wilcoxon dengan tingkat kemaknaan $p$ Value $<0,05$. Berdasarkan hasil analisis pengaruh peyuluhan perawatan bayi Berat badan Lahir Rendah (BBLR) terhadap pengetahuan ibu dalam merawat bayi pada kelompok eksperimen didapatkan nilai $p=0,03$ berarti ada hubungan bermakna antara penyuluhan perawatan bayi Berat badan Lahir Rendah (BBLR) terhadap tingkat pengetahuan ibu dalam merawat bayi Berat badan Lahir Rendah (BBLR). Pada kelompok kontrol didaptkan nilai $p=0,05$ berarti ada hubungan bermakna antara penyuluhan perawatan bayi Berat badan Lahir Rendah (BBLR) terhadap tingkat pengetahuan ibu dalam merawat bayi Berat badan Lahir Rendah (BBLR). Kesimpulan dalam penelitian ini adalah terdapat hubungan yang bermakna baik pada kelompok eksperimen maupun pada kelompok kontrol. Nilai $p$ pada kelompok eksperimen $<$ dari nilai $p$ pada kelompok kontrol. Hal ini membuktikan bahwa pada kelompok yang mendapat penyuluhan tentang perawatan bayi BBLR secara statistik mempunyai nilai kemaknaan tinggi jika dibandingkan pada kelompok kontrol. Diharapkan peneliti selanjutnya melihat pengaruh penyuluhan perawatan Berat Badan Lahir Rendah terhadap sikap dan perilaku ibu dalam merawat bayi BBLR.
\end{abstract}

\section{Kata Kunci : BBLR, Pengetahuan, penyuluhan}

\section{PENDAHULUAN}

Indikator kesehatan suatu bangsa masih di lihat dari tinggi atau rendahnya angka kematian bayi dan anak. Terjadinya kematian bayi dan anak berkaitan dengan masalah kesehatan bayi dan anak. Masalah kesehatan bayi dan anak ditiap negara berbeda. Karena perbedaan lingkungan yang mempengaruhinya. Namun secara garis besar masalah tersebut di kelompokkan menjadi dua kategori, yaitu : Masalah anak di Negara maju dan masalah anak di Negara berkembang (Maryunani, 2013).

Masalah anak dinegara berkembang yang saat ini terjadi adalah penyakit infeksi, infeksi parasit dan penyakit kurang gizi. Indonesia dikategorikan dalam Negara berkembang dengan adanya krisis ekonomi yang rendah sering dihubungkan dengan kelahiran bayi berat lahir rendah (Maryunani, 2013).Bayi berat badan lahir rendah (BBLR) adalah bayi baru lahir dengan berat badan kurang dari 2500 gram pada waktu lahir (Nurarif \& Kusuma, 2016).

Berat bayi saat lahir merupakan penentu yang paling penting untuk menentukan peluang bertahan, pertumbuhan, dan perkembangan di masa depannya. Ibu yang selalu menjaga kesehatannya dengan mengkonsumsi makanan bergizi dan menerapkan gaya hidup yang baik akan melahirkan bayi yang sehat, sebaliknya ibu yang mengalami defisiensi gizi memiliki risiko untuk melahirkan BBLR. BBLR tidak hanya mencerminkan situasi kesehatan dan gizi, namun juga menunjukkan tingkat kelangsungan hidup, dan perkembangan psikososialnya. Bayi dengan BBLR memiliki risiko lebih tinggi mengalami kematian, keterlambatan petumbuhan dan perkembangan selama masa kanak-kanak dibandingkan dengan bayi yang tidak BBLR (Rajashree, 2015). 
Menurut WHO, di seluruh dunia lahir sekitar 20 juta bayi dengan berat lahir rendah dan 19 juta diantaranya lahir di beberapa negara berkembang dengan angka insiden antara 11 persen sampai $31 \%$. Pada negara berkembang keadaan ini diperburuk oleh kekurangan nutrisi dalam kehamilan yang berdampak pada defisiensi nutrisi mikro seperti anemia yang dapat berakibat fatal pada ibu hamil dan bayi baru lahir (Setyo \& Paramita, 2015).

Menurut hasil Riskesdas tahun 2013 Persentase BBLR pada perempuan $(14,5 \%)$ lebih tinggi daripada laki-laki (10,3\%), namun persentase berat lahir $\geq 4000$ gram pada lakilaki $(6,1 \%)$ lebih tinggi dibandingkan perempuan (4,3\%) (Dinkes, 2014).

Persentase bayi dengan berat badan lahir rendah diSulawesi Selatan tahun 2014jumlah bayi lahir hidup sebesar 148.062, bayi lahir hidup ditimbang sebesar 144.864, dengan jumlah BBLR yaitu 4.376 kasus $(3,02 \%)$. Dan tertinggi di Kota Makassar sebesar 690 kasus, Kabupaten Gowa 342 kasus, dan Kabupaten Luwu 288 kasus, dan terendah di Kabupaten Barru 27 kasus, Kabupaten Bantaeng 47 kasus dan Kabupaten Tana Toraja 65 kasus (Dinkes, 2014).

Pada Tahun 2014 jumlah BBLR di Kabupaten Bone sebanyak 178 bayi dari 13.573 bayi lahir hidup atau dengan persentase $1,3 \%$. Angka ini menunjukkan peningkatan dibandingkan data tahun 2012 di Kabupaten Bone, dengan jumlah Bayi Berat Badan Lahir Rendah ( BBLR )sebanyak 121 bayi atau 0,89\%(Bone, 2015).

Salah satu faktor yang berperan penting dalam merawat bayi dengan masalah BBLR adalah pengetahuan yang cukup. Untuk meningkatkan pengetahuan dapat dilakukan melalui beberapa cara, salah satunya adalah dengan pemberian penyuluhan kesehatan. Penyuluhan kesehatan juga merupakan suatu proses yang mempunyai masukan dan keluaran untuk mencapai tujuan pendidikan yaitu perubahan perilaku. Namun ada banyak faktor yang dapat mempengaruhi keberhasilan penyuluhan tersebut seperti faktor masukan, faktor metode, faktor materi, pendidik atau petugas yang melakukannya serta alat bantu pendidikan yang dipakai. Agar hasilnya optimal, maka faktor tersebut harus bekerja secara harmonis. Tujuan penyuluhan kesehatan yaitu meningkatkan kesadaran, meningkatkan pengetahuan, mempengaruhi sikap dan persepsi untuk berperilaku, memperagakan keterampilan sederhana, memotivasi tindakan serta membangun norma. Adapun tujuan penelitian ini adalah
Untuk mengetahui pengaruh penyuluhan tentang perawatan BBLR terhadap kemampuan ibu dalam merawat bayi BBLR.

\section{BAHAN DAN METODE}

Lokasi, Populasi, dan Sampel Penelitian

Penelitian ini dilaksanakan di BLUD RS. Tenriawaru Watampone pada tanggal $13 \mathrm{Mei}$ sampai dengan 15 Juni 2019. Populasi dalam penelitian ini adalah semua ibu yang mengalami persalinan dengan bayi BBLR di Ruang Perinatology RSUD Tenriawaru Watampone yaitu sebanyak 15 orang yang tercatat dalam rekam medis pasien bulan Mei 2019. Tehnik pengumpulan sampel adalah menggunakan tehnik total sampling yitu semua anggota populasi dijadikan sampel.

1. Kriteria Inklusi

a. Ibu yang melahirkan bayi BBLR yang tercatat pada rekam medis di Ruang Perinatology BLUD RS. Tenriawaru Kab. Bone

b. Bersedia menjadi responden dan berpartisipasi aktif dalam seluruh rangkaian penelitian

2. Kriteria Esklusi

a. Ibu yang tidak ada atau tidak hadir saat dilakukan penelitian

b. Tidak berpartisipasi aktif dalam seluruh rangkaian penelitian.

\section{Pengumpulan Data}

1. Data sekunder adalah data yang diperoleh dalam bentuk jadi dan telah diolah oleh pihak lain yang biasanya dalam bentuk publikasi.

2. Data primer adalah data yang dikumpulkan dan diolah sendiri oleh suatu organisasi atau perorangan langsung dari objeknya (Saryono,

2014).

\section{Pengolahan Data}

1. Editing

Pada penelitian ini setelah data terkumpul dilanjutkan dengan kegiatan editing yaitu dengan memeriksa setiap kisioneryang diisi mengenai kebenaran data yang sesuai dengan variable

2. Pengkodean (coding)

Untuk memudahkan pengolahan data, semua jawaban atau data diberi kode. Pengkodean ini dilakukan dengan member daftar pertanyaan, nomor pertanyaan, nomor variabel dan nama variabel

3. Tabulasi Data

Setelah dilakukan kegiatan editing dan koding dilanjutkan dengan mengelompokkan data kedalam suatu 
table menurut sifat-sifat yang dimiliki sesuai dengan tujuan penelitian.

4. Analisa Data

Setelah memperoleh nilai skor dari tiap-tiap veriabel, selanjutnya Data diolah dianalisa dengan menggunakan computer program SPSS 22,0 penyajian data dalam bentuk tabel disertai penjelasan.

\section{Analisa data}

a. Analisis univariat

Untuk memberikan gambaran dalam bentuk distribusi frekuensi dari masingmasing table variabel.

b. Analisis bivariat

Analisis data ditujukan untuk menjawab tujuan penelitian menguji hipotesis penelitian. Untuk maksud tersebut, uji statistik yang akan digunakan adalah uji rangking bertanda Wilcoxon

\section{HASIL PENELITIAN}

1. Analisi Univariat

Tabel 1 Distribusi karakteristik responden Di Ruang Perinatology BLUD RS Tenriawaru Kab. Bone $2019(n=15)$

\begin{tabular}{|c|c|c|c|c|}
\hline \multirow[t]{2}{*}{ Kate-gori } & \multicolumn{2}{|c|}{$\begin{array}{r}\text { Eksperi- } \\
\text { men }\end{array}$} & \multicolumn{2}{|c|}{ Kontrol } \\
\hline & $\mathrm{n}$ & $\%$ & $\mathrm{n}$ & $\%$ \\
\hline Umur & & & & \\
\hline$<20$ & 1 & 6,7 & - & - \\
\hline $20-30$ & 6 & 40,0 & 10 & 66,7 \\
\hline$>30$ & 8 & 53,3 & 5 & 33,3 \\
\hline Pendidikan & & & & \\
\hline SD & 1 & 6,7 & - & - \\
\hline SMP & 5 & 33,3 & 5 & 33,3 \\
\hline SMU & 4 & 26,7 & 4 & 26,7 \\
\hline DIII & - & & 1 & 6,7 \\
\hline S1 & 5 & 33,3 & 5 & 33,3 \\
\hline Pekerjaan & & & & \\
\hline Tidak & 5 & 33,3 & 5 & 33,3 \\
\hline bekerja & 10 & 66,7 & 10 & 66,7 \\
\hline BBLR & & & & \\
\hline 1,8 & 1 & 6,7 & - & - \\
\hline 1,9 & 2 & 13,3 & 2 & 13,3 \\
\hline 2,0 & 1 & 6,7 & 3 & 20,0 \\
\hline 2,2 & 2 & 13,3 & 3 & 20,0 \\
\hline 2,3 & 2 & 13,3 & 2 & 13,3 \\
\hline 2,4 & 3 & 20,0 & 3 & 20,0 \\
\hline 2,5 & 4 & 26,7 & 2 & 13,3 \\
\hline ANAK KE & & & & \\
\hline 1 & 1 & 6,7 & 6 & 40,0 \\
\hline 2 & 7 & 46,7 & 4 & 26,7 \\
\hline 3 & 3 & 20,0 & 2 & 13,3 \\
\hline 4 & 2 & 13,3 & 2 & 13,3 \\
\hline 5 & 1 & 6,7 & 1 & 6,7 \\
\hline 6 & 1 & 6,7 & - & - \\
\hline
\end{tabular}

Tabel 1 di atas memperlihatkan karakteristik responden. Dari tabel tersebut dapat diketahui bahwa berdasarkan karakteristik umur, responden terbanyak pada usia > 30 tahun yaitu sebanyak 8 orang $(53,3 \%)$, terendah pada usia $<20$ tahun yaitu sebanyak 1 orang $(6,7 \%)$, Tingkat pendidikan responden, yang terbanyak ada dua yaitu SMP dan S1 sebanyak 5 orang $(33,3 \%)$, terendah SD sebanyak 1 orang $(6,7 \%)$. jenis pekerjaan responden yang terbanyak yaitu yang tidak bekerja sebanyak 10 orang $(66,7 \%)$ sedangkan yang bekerja sebanyak 5 orang $(33,3 \%)$. Berdasarkan berat badan lahir bayi yang terbanyak pada berat 2500 gram sebanyak 4 orang $(26,7 \%), 2400$ gram sebanyak 3 orang (20,0\%), 1900 gram, 2200 gram dan 2300 gram masing-masing sebanyak 2 orang $(13,3 \%)$ dan terendah pada berat 1800 gram dan 2000 gram sebanyak 1 orang (6,7\%). Berdasarkan urutan saudara dari bayi yang terbanyak pada anak ke dua sebanyak 7 orang $(46,7 \%)$, Sedangkan terendah pada anak ke 1,5 dan 6 masing-masing satu orang $(6,7 \%)$.

karakteristik responden kelompok kontrol. Dari tabel tersebut dapat diketahui bahwa berdasarkan karakteristik umur , responden terbanyak pada usia 20-30 tahun yaitu sebanyak 10 orang $(66,7 \%)$, terendah pada usia $>30$ tahun yaitu sebanyak 5 orang (33,3\%). Tingkat pendidikan responden, yang terbanyak ada dua yaitu SMP dan S1sebanyak 5 orang $(33,3 \%)$, Terendah D3 sebanyak 1 orang $(6,7 \%)$. Jenis pekerjaan responden yang terbanyak yaitu yang tidak bekerja sebanyak 10 orang $(66,7 \%)$ sedangkan yang bekerja sebanyak 5 orang (33,3\%). Berat badan lahir bayi yang terbanyak pada berat 2000 gram, 2200gram, 2400 gram masing-msing sebanyak 3 orang $(20,0 \%)$, sedangkan terendah pada berat 1900 gram, 2300 gram dan 2500 gram sebanyak 2 orang (13,3\%). bersaudara dari bayi yang terbanyak pada anak pertama sebanyak 6 orang $(40,0 \%)$, Sedangkan terendah pada anak ke 5 sebanyak satu orang $(6,7 \%)$. 
2. Hasil Bivariat

Tabel 2 Hasil analisa pengaruh penyuluhan tentang perawatan BBLR terhadap pengetahuan ibu dalam merawat bayi BBLR pre test dan post test pada kelompok eksperimen.

\begin{tabular}{|l|c|c|c|c|}
\hline \multirow{2}{*}{$\begin{array}{c}\text { Kriteria } \\
\text { Pengetauan }\end{array}$} & \multicolumn{2}{|c|}{$\begin{array}{c}\text { Sebelum } \\
\text { penyuluhan }\end{array}$} & \multicolumn{2}{c|}{$\begin{array}{c}\text { Sesudah } \\
\text { Penyuluhan }\end{array}$} \\
\cline { 2 - 5 } & $\mathrm{n}$ & $\%$ & $\mathrm{n}$ & $\%$ \\
\hline Baik & 6 & 40 & 15 & 100 \\
\hline Kurang & 9 & 60 & - & - \\
\hline Total & 15 & 100 & 15 & 100 \\
\hline
\end{tabular}

Tabel 2 menggambarkan pengaruh penyuluhan terhadap pengetahuan ibu dalam merawatan bayi BBLR yang sebelum diberikan penyuluhan dari 15 responden, sebagian responden masih mempunyai tingkat pengetahuan yang kurang yaitu 9 responden $(60 \%)$ sedangkan tingkat pengetahuan baik terdapat 6 responden (40\%). Setelah diberikan penyuluhan perawatan bayi BBLR maka semua responden mengalami peningkatan pengetahuan tentang perawatan bayi BBLR. Responden dengan tingkat pengetahuan baik 15 responden $(100 \%)$.

Tabel 3 Distribusi frekuensi pengaruh penyuluhan terhadap perwatan bayi BBLR terhadap pengetahuan ibu pada kelompok eksperimen $(n=15)$ dan kelompok kontrol $(n=15)$.

\begin{tabular}{|c|c|c|c|c|}
\hline Hasil & $\begin{array}{l}\text { Tanda } \\
\text { Jen-jang }\end{array}$ & $\mathrm{n}$ & $\%$ & Z \\
\hline \multirow{3}{*}{$\begin{array}{l}\text { Pre test } \\
\text { pengetahu } \\
\text { an ibu klp } \\
\text { Ekspe- } \\
\text { rimen }\end{array}$} & $\begin{array}{l}\text { Rang- } \\
\text { king } \\
\text { negatif }\end{array}$ & 9 & 60 & \multirow{3}{*}{$-3,000$} \\
\hline & $\begin{array}{c}\text { Rangking } \\
\text { positif }\end{array}$ & 0 & 0 & \\
\hline & Tetap & 6 & 40 & \\
\hline \multicolumn{2}{|l|}{ Total } & 15 & 100 & \\
\hline \multicolumn{5}{|c|}{ Asymp Sig (z-tailed) $=0,03$} \\
\hline \multirow{3}{*}{$\begin{array}{c}\text { Pre test } \\
\text { pengetahu } \\
\text { an ibu klp } \\
\text { Kontrol }\end{array}$} & $\begin{array}{c}\text { Rangking } \\
\text { negatif }\end{array}$ & 0 & 0 & \multirow{3}{*}{$-2,8$} \\
\hline & $\begin{array}{c}\text { Rangking } \\
\text { positif }\end{array}$ & 8 & 53,3 & \\
\hline & Tetap & 7 & 46,6 & \\
\hline \multicolumn{2}{|l|}{ Total } & 15 & 100 & \\
\hline \multicolumn{5}{|c|}{ Asymp Sig (z-tailed) $=0,05$} \\
\hline
\end{tabular}

Pada tabel 3 terlihat bahwa untuk kelompok eksperimen dengan jumlah 15 responden yang menunjukkan nilai posttest < pretes (Rangkin negatif) 9 orang atau $60 \%$, nilai posttest > pretest (rangking positif) 0 orang atau $0 \%$, dan nilai posttest $=$ pretest berjumlah 6 orang atau $40 \%$. Dari hasil uji rangking bertanda Wilcoxon dengan menggunakan statistic $Z$, didapatkan nilai untuk kelompok eksperimen $-3,000$ dengan taraf kesalahan 0,03 dan tingkat kepercayaan 100\%. Sedangkan pada kelompok kontrol dengan jumlah 15 responden yang menunjukkan nilai posttest $<$ pretest (rangking negatif) 0 orang atau $0 \%$, nilai posttest $>$ pretest (rangking positif) 8 orang atau $53,3 \%$ dan posttest $=$ pretest 7 orang atau $46,6 \%$. Pada tabel diatas terlihat bahwa kelompok kontrol, nilai $Z=-2,828$ dengan taraf kesalahan 0,05 dengan tingkat kepercayaan $100 \%$.

Dengan demikian nilai kapasitas uji dua pihak (2 Tailed), terlihat bahwa pada kelompok eksperimen nilai $P=0,03$ dan kelompok kontrol $P=0,05$ berarti nilai $P$ untuk kelompok eksperimen < nilai $\mathrm{P}$ kelompok kontrol. Sehingga perbandingan nilai ini menunjukkan bahwa kelompok eksperimen yang diberikan perlakuan penyuluhan perawatan bayi BBLR memberikan hasil yang bermakna. Jadi ada pengaruh penyuluhan perawatan BBLR terhadap kemampuan tingkat pengetahuan ibu dalam merawat bayi BBLR.

\section{PEMBAHASAN}

Pengaruh penyuluhan tentang perawatan Berat Badan Lahir Rendah (BBLR) terhadap pengetahuan ibu dalam merawat bayi BBLR di ruang perinatology RSUD Tenriawaru Kelas $B$ Kab. Bone.

Berdasarkan hasil penelitian yang dilakukan bahwa 15 responden kelompok eksperimen yang diberikan penyuluhan tentang perawatan bayi BBLR, semua responden mengalami peningkatan pengetahuan tentang perawatan bayi BBLR. Responden dengan tingkat pengetahuan baik 15 responden $(100 \%)$ sedangkan hasil yang didapatkan pada kelompok kontrol, dimana pre test dan post test tidak mengalami peningkatan karena tanpa penyuluhan yaitu 7 responden $(46,7 \%)$ mempunyai tingkat pengetahuan kurang, sedangkan 8 responden $(53,3 \%)$ mempunyai tingkat pengetahuan 
baik. Walaupun dalam hasil yang didapatkan pada kelompok kontrol terdapat nilai yang tetap setelah dilakukan penyuluhan.

Setelah dilakukan uji Wilcoxon terlihat bahwa pada kelompok eksperimen nilai $P=$ 0,03 dan kelompok kontrol $P=0,05$ berarti nilai $\mathrm{P}$ untuk kelompok eksperimen < dari nilai $\mathrm{P}$ kelompok kontrol. Sehingga perbandingan nilai ini menunjukkan bahwa kelompok eksperimen yang diberikan perlakuan penyuluhan perawatan bayi BBLR memberikan hasil yang bermakna. Jadi ada pengaruh penyuluhan perawatan BBLR terhadap kemampuan tingkat pengetahuan ibu dalam merawat bayi BBLR.

Hasil penelitian ini sejalan dengan peneltian tentang Pengaruh pendidikan kesehatan mulut berbasis sekolah untuk mencegah karies gigi terhadap dan peningkatan pengetahuan, sikap dan praktik di kalangan remaja di Indonesia dan Bangladesh. Penelitian ini menunjukkan bahwa intervensi penyuluhan kesehatan tentang kebersihan mulut dapat meningkatkan pengetahuan, sikap dan secara signifikan dapat menurunkan jumlah karies gigi (Haque, Rahman, Itsuko, Mutahara, \& Kayako, 2016). Penelitian ini sejalan pula dengan penelitian tentang Efektifitas pendidikan kesehatan mulut terhadap peningkatan pengetahuan, sikap, praktik, dan status kebersihan mulut di antara anak sekolah berusia 12-15 tahun dari para nelayan di distrik Kutch, Gujarat, India. Hasil penelitiannya menunjukkan bahwa intervensi berbasis sekolah dasar yang mudah dan murah dalam jangka pendek ini efektif dalam meningkatkan kebersihan mulut anak-anak (Sanadhya, Thakkar, Divakar, \& Pareek, 2014).

Penelitian lain tentang Efektifitas dari pendidikan kesehatan terhadap pengetahuan, sikap, dan manajemen pertolongan pertama terhadap epilepsi. Hasil penelitian ini menunjukkan bahwa pendidikan kesehatan yang diberikan melalui guru efektif dalam meningkatkan pengetahuan, sikap serta pertolongan pertama pada penderita epilepsi (Eze, Ebuehi, Brigo, Otte, \& Igwe, 2015). Selain itu penelitian lain tentang pengaruh pendidikan kesehatan dengan pendekatan modeling terhadap pengetahuan, kemampuan praktek dan percaya diri ibu dalam menstimulasi tumbuh kembang bayi 0-6 bulan di kabupaten maros. Penelitian ini menunjukkan bahwa Pendidikan kesehatan dengan pendekatan modelling yang dilakukan perawat efektif dalam meningkatkan pengetahuan, kemampuan praktek, kepercayaan diri ibu dalam pemberian ASI dan menstimulasi bayi, yang pada akhirnya dapat mengoptimalkan tumbuh tumbuh kembang bayi.

Penyuluhan kesehatan adalah penambahan pengetahuan dan kemampuan seseorang melalui teknik praktik belajar atau instruksi dengan tujuan mengubah atau mempengaruhi perilaku manusia secara individu, kelompok maupun masyarakat untuk dapat lebih mandiri dalam mencapai tujuan hidup sehat (Heri. D. J maulana, 2007).

Penyuluhan pearawatan merupakan salah satu kompetensi yang dituntut dari tenaga keperawatan, karena merupakan salah satu peranan yang harus dilaksanakan dalam setiap pemberian asuhan keperawatan dimana saja ia bertugas. Dengan demikian seorang perawat harus mampu menjalankan perannya dalam memberikan penyuluhan perawatan kepada individu, keluarga, masyarakat maupun kelompok khusus, apakah itu dirumah sakit, klinik, puskesmas, rumah bersalin, dan di rumah dalam merubah perilaku mereka kearah perilaku sehat.

Dari beberapa hasil penelitan dan literature yang menyatakan bahwa penyuluhan perawatan identik dengan pendidikan kesehatan karena keduanya berorientasi kepada peningkatan pengetahuan seseorang yang dimana dari tidak tahu menjadi tahu. Oelh karena itu pencapaian target penyuluhan jangka pendek yaitu tercapainya peningkatan pengetahuan. Adapun target penyuluhan jangka menengah pada pemberian penyuluhan adalah tercapainya perubahan perilaku, sikap dan dan keterapilan dalam merubah perilaku tersebut. Sedangkan ujuan jangkapanjang penyuluhan adalah dapat menjalankan perilaku sehat dalam kehidupan sehari-harinya.

Salah satu pengaruh tercapainya tujuan dari penyuluhan ini adalah peningkatan pengetahuan bagidalam meraat bayi BBLR. Keberhasilan penyuluhan yang dilakukan oleh penelti disebabkan sadarnya ibu tentang 
pentingnya penyuluhan, jalinan hubungan antara penyuluh dan responden serta dukungan dari pihak terkait seperti perawat dan petugas kesehatan lainnya sehingga penyuluh menyampaikan materi dan dapat meningkatkan pengetahuan.

\section{KESIMPULAN}

Pemberian intervensi berupa penyuluhan tentang perawatan bayi BBLR dapat meningkatkan pengetahuan. Hal ini disebabkan oleh adaya kesardaan ibu tentang pentingnya mengikuti penyuluhan. Tehnik penyuluhan kesehatan sangat efektif dalam meningkatkan pengetahuan.

\section{SARAN}

Bagi peneliti selanjutnya diharapkan untuk meneliti tentang perubahan perilaku dan sikap setelah terjadi peningkatan pengetahuan setelah diberikan penyuluhan.

\section{DAFTAR PUSTAKA}

Dinkes. (2014). Profil Kesehatan Provinsi Sulawesi Selatan 2014. Makassar.

Effendy. Dasar-dasar Keperawatan Kesehatan Masyarakat. Jakarta: Buku Kedokteran EGC; 1997.p. 232-43.

Eze, C. N., Ebuehi, O. M., Brigo, F., Otte, W. M., \& Igwe, S. C. (2015). Effect of health education on trainee teachers ' knowledge, attitudes, and first aid management of epilepsy: An interventional study. Seizure: European Journal of Epilepsy, 33, 46-53. http://doi.org/10.1016/j.seizure.2015.10.014

Haque, S. E., Rahman, M., Itsuko, K., Mutahara, M., \& Kayako, S. (2016). Effect of a school-based oral health education in preventing untreated dental caries and increasing knowledge, attitude, and practices among adolescents in Bangladesh. BMC Oral Health, 1-10. http://doi.org/10.1186/s12903-016-0202-3

Heri D. J Maulana. 2007. Promosi Kesehatan. Jakarta. EGC.

Kesehatan, P., \& Bone, K. (2015). Profil Kesehatan Kabupaten Bone.

Maryunani, A. (2013). Buku Saku Asuhan Bayi Dengan Berat Badan Lahir Rendah. Jakarta: TIM.

Nurarif, A. H., \& Kusuma, H. (2016). Asuhan Keperawatan Praktis Berdasarkan Penerapan Diagnosa Nanda, NIC, NOC Dalam Berbagai Kasus. Jogjakarta: Mediaction.

Sanadhya, Y. K., Thakkar, J. P., Divakar, D. D., \& Pareek, S. (2014). Effectiveness of oral health education on knowledge, attitude, practices and oral hygiene status among $12-15$-year-old schoolchildren of fishermen of Kutch district , Gujarat , India, 99-105. http://doi.org/10.5603/IMH.2014.0022

Setyo, M., \& Paramita, A. (2015). POLA KEJADIAN dan determinan BAYI DENGAN Berat Badan Lahir Rendah ( BBLR ) DI INDONESIA tahun 2013 ( Pattern of Occurrence and Determinants of Baby, 2013, 1-10. 